\title{
Colchicine overdose with coingestion of nonsteroidal antiinflammatory drugs
}

\author{
Anjuli Little, MD, BSc*; David Tung, PharmD ${ }^{\dagger}$; Christine Truong, BScPharm ${ }^{\ddagger}$; \\ Stephen Lapinsky, MD*; Lisa Burry, BScPharm, PharmD ${ }^{\S}$
}

\section{ABSTRACT}

Colchicine has a low therapeutic index. Its toxic effects generally occur at doses $\geq 0.5 \mathrm{mg} / \mathrm{kg}$. We present the case of a 39-year-old female with toxicity following ingestion of $0.28 \mathrm{mg} / \mathrm{kg}$. The patient presented to the emergency department (ED) with severe nausea, vomiting, and abdominal pain following an intentional multidrug ingestion that included colchicine, indomethacin, and zopiclone. Despite toxicologic management and supportive care, admission to the intensive care unit was required for clinical deterioration and symptom management. Shock and multiorgan failure resulted, with death occurring 52 hours postingestion. Although the toxic effects of colchicine are well documented, mortality caused by low doses is relatively uncommon. Management of toxicity consists of early diagnosis, decontamination, and supportive measures. Toxicity may be enhanced by drug interactions inhibiting metabolic enzymes or poor excretion due to renal failure. In this case, the ingestion of a nonsteroidal antiinflammatory drug and the associated volume depletion from the gastrointestinal effects of colchicine may have contributed to renal dysfunction, exacerbating the toxicity of colchicine. This ingestion of a relatively small dose of colchicine led to severe toxicity. Treatment options for colchicine toxicity are limited.

\section{RÉSUMÉ}

La colchicine a un faible indice thérapeutique. Ses effets toxiques se manifestent généralement à des doses $\geq 0.5 \mathrm{mg} / \mathrm{kg}$. Sera exposé le cas d'une femme de 39 ans chez qui des signes de toxicité sont apparus après l'ingestion de $0.28 \mathrm{mg} / \mathrm{kg}$ de colchicine. La patiente a consulté au service des urgences pour de fortes nausées, des vomissements et des douleurs abdominales à la suite de l'ingestion volontaire d'un cocktail médicamenteux, composé de colchicine, d'indométhacine et de zopiclone. Malgré une prise en charge toxicologique et des soins de soutien, il a été nécessaire d'admettre la patiente au service des soins intensifs pour une détérioration de l'état clinique et la prise en charge des symptômes. S'en sont suivis un état de choc et une défaillance multiorganique, qui se sont soldés par la mort de la patiente 52 heures après la prise des médicaments. Les effets toxiques de la colchicine sont bien connus, mais il est plutôt rare que de faibles doses de ce médicament entraînent la mort. La prise en charge de la toxicité comprend la pose précoce du diagnostic, la décontamination et des mesures de soutien. La toxicité peut être aggravée par les interactions médicamenteuses qui inhibent les enzymes métaboliques ou par la faible excrétion due à l'insuffisance rénale. Dans le cas ici exposé, l'ingestion d'un anti-inflammatoire non stéroïdien et la déplétion du volume des liquides résultant des effets gastro-intestinaux de la colchicine ont pu jouer un rôle dans le dysfonctionnement rénal, d'où l'intensification de la toxicité de la colchicine. Ainsi, la prise d'une dose relativement faible de colchicine a produit des effets toxiques graves, et les possibilités de traitement de la toxicité de la colchicine sont peu nombreuses.

Keywords: coingestion, colchicine, nonsteroidal antiinflammatory drug, overdose

Colchicine, an alkaloid extracted from the plants Colchicine autumnale (autumn crocus) and Gloriosa superba (glory lily), has been used to treat gout for almost 1,500 years. ${ }^{1}$ Colchicine interferes with cellular division by suppressing neutrophil activity in joints, thereby decreasing inflammation. It also affects other systems, such as the gastrointestinal (GI) tract, that have high cellular turnover rates. ${ }^{2-5}$

Colchicine is metabolized in the liver by cytochrome P-450 3A4 (CYP3A4). P-glycoprotein (P-gp) helps excrete the drug by inhibiting GI absorption and stimulating efflux from hepatocytes. Twenty percent of unchanged colchicine is excreted by the kidneys. ${ }^{6,7}$

From the *Faculty of Medicine, University of Toronto; †Department of Pharmacy Services, Medisystems Inc; $¥$ Department of Pharmacy Services, St. Joseph's Hospital; and §Department of Pharmacy Services, Mount Sinai Hospital, Toronto, ON.

Correspondence to: Dr. Lisa Burry, Department of Pharmacy Services, Mount Sinai Hospital, Toronto, ON; Iburry@mtsinai.on.ca.

This article has been peer reviewed. 
Administration of colchicine with inhibitors of CYP3A4 and/or P-gp may exacerbate toxicity. Drug clearance is reduced in those with renal and/or hepatic insufficiency.

Widespread use of colchicine is limited by its recognized toxicity, even though the literature about clinical toxicity is limited. Overdose is difficult to manage as there is no antidote. Toxicity has been reported with doses $\geq 0.5 \mathrm{mg} / \mathrm{kg}$, with death possible when ingestion exceeds $0.8 \mathrm{mg} / \mathrm{kg} .{ }^{8}$ We present a case of a fatal multidrug overdose after ingestion of a $25 \mathrm{mg}$ $(0.28 \mathrm{mg} / \mathrm{kg})$ dose of colchicine.

\section{CASE SUMMARY}

A 39-year-old, $90 \mathrm{~kg}$ female presented to the emergency department (ED) at 4:00 am with severe nausea, vomiting, abdominal pain, and diarrhea following the intentional ingestion of multiple medications. The patient's husband reported that the couple went to bed at 12:00 am. He found his wife vomiting tablets at 2:00 am. He noted that she had ingested his medications: 40 tablets of colchicine $(25 \mathrm{mg}$ or $0.28 \mathrm{mg} / \mathrm{kg}$ ), 50 tablets of indomethacin $(1.25 \mathrm{~g})$, and 10 tablets of zopiclone $(75 \mathrm{mg})$. The patient reported use of personal medications (topiramate, valproic acid, olanzapine, lorazepam, levothyroxine, oxycodone, furosemide, omeprazole) prior to admission but was unable to specify timing or doses. The patient denied use of over-the-counter or herbal medications. Her past medical history was significant for bipolar affective disorder, hypothyroidism, reflux disease, multiple suicide attempts involving multidrug overdose, and illicit drug use.

The ED admission vital signs are shown in Table 1. Preliminary bloodwork revealed increased white blood cells (WBCs) with a normal platelet count. Serum creatinine was elevated (Table 2), whereas other investigations found a serum lactate of $0.86 \mathrm{mmol} / \mathrm{L}$, an international normalized ratio (INR) of 2.4, and a troponin $\mathrm{T}$ of 0.02 (normal $<0.01$ ). Urine toxicology screening was negative except for benzodiazepines. Alcohol, salicylate, and acetaminophen levels were negative. The electrocardiogram (ECG) and chest radiograph were normal.

Preliminary management included administration of two doses of activated charcoal $(50 \mathrm{~g})$ and intravenous (IV) hydration of a total $6 \mathrm{~L} \mathrm{NaCl} 0.9 \%$ over 6 hours with $4 \mathrm{~L}$ by bolus because of hemodynamic compromise at 6 hours postingestion (see Table 1). Repeat urine toxicology screening remained negative for alcohols, salicylates, and acetaminophen and was negative for cocaine, cannabinoids, opiates, amphetamines, and barbiturates.

Approximately 8 hours postingestion, the patient remained alert and oriented. Worsening vital signs (see Table 1), severe shortness of breath, and abdominal pain requiring intermittent IV fentanyl prompted transfer to the intensive care unit (ICU). As per the advice of the Ontario Poison Centre, she received multidose activated charcoal (MDAC) for enhanced elimination, additional fluid boluses, and vitamin $\mathrm{K}$ (10 mg by IV) due to the elevated INR. At 18 hours postingestion, vital signs continued to worsen (see Table 1), with reduced urine output (see Table 2). Arterial blood gases demonstrated metabolic acidosis: $\mathrm{pH} 7.20$, carbon dioxide partial pressure $14.9 \mathrm{~mm} \mathrm{Hg}$, and bicarbonate $6.6 \mathrm{mEq} / \mathrm{L}$. The patient was intubated. An IV norepinephrine infusion titrated to maintain mean arterial pressure $(\mathrm{MAP}) \geq 60 \mathrm{~mm} \mathrm{Hg}$ was started. She received $100 \mathrm{mEq} \mathrm{NaHCO}_{3} \mathrm{IV}$ and $400 \mu \mathrm{g}$ phenylephrine IV.

Over the next 24 hours, WBC and platelet counts declined (see Table 2). At 28 hours postingestion, her

\begin{tabular}{|c|c|c|c|c|c|}
\hline Postingestion time (h) & $\begin{array}{l}\text { Blood pressure } \\
(\mathrm{mm} \mathrm{Hg})\end{array}$ & $\begin{array}{l}\text { Heart rate } \\
\quad(\mathrm{bpm})\end{array}$ & $\begin{array}{l}\text { Respiratory rate } \\
\text { (per min) }\end{array}$ & $\begin{array}{c}\text { Temperature, } \\
{ }^{\circ} \mathrm{C}\left({ }^{\circ} \mathrm{F}\right)\end{array}$ & $\begin{array}{c}\text { Mean arterial } \\
\text { pressure }(\mathrm{mm} \mathrm{Hg})\end{array}$ \\
\hline 2 & $143 / 49$ & 77 & 24 & $34.7(94.4)$ & \\
\hline 6 & $70 / 50$ & 110 & 30 & & \\
\hline 8 & $116 / 78$ & 106 & 40 & $36.7(98)$ & 100 \\
\hline 18 & $90 / 50$ & 130 & 41 & & 65 \\
\hline 28 & $80 / 58$ & 135 & 45 & 39.9 (103.8) & 70 \\
\hline 35 & $98 / 61$ & 142 & & $39.8(103.6)$ & 75 \\
\hline 50 & $86 / 51$ & 143 & 40 & $40.0(104)$ & 65 \\
\hline 52 & $30 / 27$ & 96 & 40 & $40.0(104)$ & 28 \\
\hline
\end{tabular}




\begin{tabular}{|c|c|c|c|c|c|c|c|}
\hline $\begin{array}{l}\text { Postingestion } \\
\text { time (h) }\end{array}$ & $\begin{array}{c}\text { WBCs }\left(\times 10^{3} / \mu \mathrm{L}\right) \\
(3.0-10.0)\end{array}$ & $\begin{array}{l}\text { Platelets }\left(\times 10^{3} / \mu \mathrm{L}\right) \\
\qquad(130-400)\end{array}$ & $\begin{array}{l}\text { AST (IU/L) } \\
(4-36)\end{array}$ & $\begin{array}{l}\text { ALT (IU/L) } \\
(0-36)\end{array}$ & $\begin{array}{l}\text { CK (IU/L) } \\
(38-176)\end{array}$ & $\begin{array}{c}\mathrm{SCr}(\mu \mathrm{mol} / \mathrm{L}) \\
(44-124)\end{array}$ & $\begin{array}{l}\text { Urine output } \\
\qquad(\mathrm{mL} / \mathrm{h})\end{array}$ \\
\hline 3 & 46.36 & 359 & & & 275 & 292 & \\
\hline 4 & 39.29 & 320 & 200 & 30 & 209 & 310 & \\
\hline 18 & 30.75 & 207 & 469 & 165 & 288 & 301 & 12 \\
\hline 21 & 24.27 & 150 & 801 & 345 & 364 & 274 & 12 \\
\hline 28 & 9.26 & 104 & 3,420 & 1,050 & 3,740 & 292 & 12 \\
\hline 35 & 2.79 & 39 & & & & 274 & 30 \\
\hline 45 & 0.54 & 26 & 3,470 & 800 & 4,100 & 327 & 10 \\
\hline 47 & 0.29 & 81 & 3,650 & 827 & 4,640 & 345 & 10 \\
\hline 50 & 0.31 & 69 & 4,100 & 982 & 5,840 & 380 & $<10$ \\
\hline
\end{tabular}

condition deteriorated further (see Table 1) despite continuous fluid resuscitation and an increasing rate of norepinephrine infusion. A bicarbonate infusion was initiated. MDAC was continued-50 $\mathrm{g}$ charcoal in sorbitol alternating with $50 \mathrm{~g}$ in water every 2 hours. Further blood work revealed worsening serum creatinine levels (see Table 2).

Continuous IV infusions of midazolam and morphine were initiated at 35 hours postingestion for severe pain, agitation, and respiratory distress not relieved with hourly IV fentanyl $(100 \mu \mathrm{g})$. Further doses of bolus IV fluid replacement were required to maintain $\mathrm{MAP} \geq 60 \mathrm{~mm} \mathrm{Hg}$. A dose of granulocyte colony-stimulating factor (G-CSF) $(480 \mu \mathrm{g}$ IV) was given in response to the drop in WBCs to $2.79 \times 10^{3} / \mu \mathrm{L}$, and the patient received 5 units of platelets and 1 unit of packed red blood cells. No growth occurred in urine, sputum, and blood cultures taken in the ED. The patient remained febrile, with poor vital signs (see Table 1). A subsequent chest radiograph revealed significant left lower lung infiltrates. An abdominal radiograph showed no evidence of perforation. Treatment with piperacillin/ tazobactam $3.375 \mathrm{mg}$ IV was administered at this point for febrile neutropenia and probable septic shock. Rifampin $600 \mathrm{mg}$ IV was given in an attempt to induce the metabolism of colchicine.

Despite aggressive management, the patient remained tachycardic, tachypneic, and febrile, with hypotension unresponsive to fluids and a low WBC count (see Table 1 and Table 2). Nitric oxide inhalation and neuromuscular blockade with $15 \mathrm{mg}$ IV bolus followed by a $20 \mathrm{mg} / \mathrm{h}$ infusion of cisatracurium were initiated to control worsening ventilation, without effect. The patient succumbed to multiorgan failure 52 hours postingestion.

\section{DISCUSSION}

Recommendations for the management of colchicine poisoning include GI decontamination and aggressive supportive measures. ${ }^{2}$ Investigations should include basic bloodwork, chest radiography, urinalysis, continuous ECG monitoring, and toxicology screening. ${ }^{9-11}$ Diagnosis of colchicine overdose is based on a threestage clinical presentation and documented ingestion history. Stage 1 includes nausea, vomiting, profuse diarrhea, and abdominal pain associated with hypovolemia and leukocytosis. Typical onset is 2 to 8 hours postingestion and lasts from 24 to 48 hours..$^{10,12,13}$ Stage 2 is marked by the development of multiorgan failure with metabolic derangements, occurring 1 to 7 days postingestion. Cardiac arrhythmias, acute respiratory distress syndrome, renal failure, electrolyte disturbances, bone marrow suppression, and coagulopathies are all frequent manifestations. Death is commonly due to hemodynamic collapse, cardiac arrhythmias, and infectious or hemorrhagic complications. ${ }^{12-14}$ Stage 3 for survivors is recovery. This occurs 7 to 21 days postingestion with resolution of organ system derangements and recovery of bone marrow function. ${ }^{15}$

For early ingestions, use of gastric lavage and activated charcoal may be beneficial. ${ }^{16}$ Enhanced elimination with MDAC should be considered due to colchicine's enterohepatic recirculation. ${ }^{9}$ This is especially true for potentially lethal ingestions as no methods of extracorporeal elimination are useful for this drug. ${ }^{17}$

Supportive care should take place in an ICU due to the high probability risk of deterioration and septic shock. The use of vasopressor and antiarrhythmic medications may be indicated. Mechanical ventilation 
should be considered for respiratory compromise, and broad-spectrum antibiotics will be required for febrile patients. ${ }^{11,15}$ In our case, activated charcoal was given as part of an overdose regimen for colchicine and all coingested medications. G-CSF, rifampin, and supportive measures were suggested by the Ontario Poison Centre to treat the worsening clinical presentation of the patient. At least eight case reports have shown successful use of G-CSF in shortening the duration of neutropenia following colchicine overdose. $^{14,18}$ Harris and colleagues described three cases where G-CSF was administered on day 4 or 5 postingestion..$^{18}$ Following 2 to 3 days of daily dosing, WBCs began to recover and platelet levels improved. In our case, WBC and platelets exhibited a fourfold decline 28 hours postingestion. Consequently, the single dose of G-CSF $480 \mu \mathrm{g}(5 \mu \mathrm{g} / \mathrm{kg})$ was administered much earlier on day 2 postingestion. Administration of rifampin has been theorized to promote the excretion of colchicine via $\mathrm{P}$-gp induction and increased metabolism by CYP3A4. ${ }^{19-21}$ No case reports attempting this treatment were found. In our case, $600 \mathrm{mg}$ IV rifampin was given, with no obvious improvement. It remains uncertain whether earlier administration would have impacted this case.

Based on the history provided, our patient consumed a relatively small dose of colchicine yet experienced lethal toxic effects, developing early-onset acute renal failure (ARF). Although unusual, this was similar to a case of a 37-year-old woman who presented after ingesting $15 \mathrm{mg}$ colchicine with severe toxicity suggested to be associated with early ARF. ${ }^{12}$ Volume depletion is a serious side effect of colchicine intoxication and is often a fundamental cause of ARF. A case report described a 48-year-old man who ingested $10 \mathrm{mg}$ colchicine and later developed ARF that was attributed to the combination of colchicine and hypovolemia.22 Our patient ingested multiple medications, including indomethacin, prompting us to consider the additive renal toxicity seen with nonsteroidal antiinflammatory drugs (NSAIDs) as a causative factor in her early-onset ARF. The evidence suggests that indomethacin toxicity can result in ARF alone or in the presence of volume depletion. ${ }^{23-25}$ One case described a 47-year-old man who suffered ARF postingestion of $20 \mathrm{mg}(0.22 \mathrm{mg} / \mathrm{kg})$ of colchicine with $600 \mathrm{mg}$ of indomethacin. ${ }^{26}$ ARF was attributed to the overdose of colchicine due to various factors, principally volume depletion. The authors stated that it was probable that indomethacin had a role in the development of ARF, potentially a result of kidney tubular damage due to indomethacin's inhibition of prostaglandin synthesis, which hinders efferent arteriolar vasodilation. Support for this theory was outlined by Venturini and colleagues, who described ARF in a small subset of patients taking NSAIDs, particularly in already volume-depleted patients. ${ }^{27}$

\section{CONCLUSIONS}

Colchicine toxicity is rare and can be life-threatening, requiring timely clinical recognition and management. The role of aggressive fluid resuscitation needs to be highlighted as our patient's fatal outcome may have resulted from early development of renal failure brought on by a combination of factors, including septic shock and hypovolemia with concomitant NSAID consumption.

Competing interests: None declared.

\section{REFERENCES}

1. Hartung EF. History of the use of colchicum and related medicaments in gout with suggestions for further research. Ann Rheum Dis 1954;13:190-200, doi:10.1136/ard.13.3.190.

2. Finkelstein Y, Aks SE, Hutson JR, et al. Colchicine poisoning: the dark side of an ancient drug. Clin Toxicol 2010;48:407-14, doi:10.3109/15563650.2010.495348.

3. Hood RL. Colchicine poisoning. 7 Emerg Med 1994;12:1717, doi:10.1016/0736-4679(94)90695-5.

4. Seegmiller JE, Howell RR, Malawista SE. Mechanism of action of colchicine in acute gouty arthritis. 7 Clin Invest 1962;41:1399, doi:10.1172/JCI104560.

5. Rochdi M, Sabouraud A, Baud FJ, et al. Toxicokinetics of colchicine in humans: analysis of tissue, plasma and urine data in ten cases. Hum Exp Toxicol 1992;11:510-6, doi:10.1177/096032719201100612.

6. Hunter AL, Klaasen CD. Biliary excretion of colchicine. 7 Pharmacol Exp Ther 1975;192:605-17.

7. Girre C, Thomas G, Scherrmann JM, et al. Modelindependent pharmacokinetics of colchicine after oral administration to healthy volunteers. Fundam Clin Pharmacol 1989;3: 537-43, doi:10.1111/j.1472-8206.1989.tb00688.x.

8. Bismuth C, Gaultier M, Conso F. Medullary aplasia after acute colchicine poisoning. 20 cases. Nouv Presse Med 1977;6: 1625-9.

9. Borron SW, Scherrmann JM, Baud FJ. Markedly altered colchicine kinetics in a fatal intoxication: examination of contributing factors. Hum Exp Toxicol 1996;15:885-90, doi: $10.1177 / 096032719601501104$.

10. Maxwell MJ, Muthu P, Pritty PE. Accidental colchicine overdose: a case report and literature review. Emerg Med 7 2002;19:265-7, doi:10.1136/emj.19.3.265. 
11. Donovan JW. Colchicine. In: Shannon MW, Borron SW, Burns MJ, editors. Haddad and Winchester's clinical management of poisoning and drug overdose. Philadelphia: Saunders/ Elsevier; 2007.

12. Dickinson M, Juneja S. Hematological toxicity of colchicine. Br 7 Hematol 2009;146:465, doi:10.1111/j.1365-2141.2009. 07581.x.

13. Brvar M, Ploj T, Kozelj G, et al. Case report: fatal poisoning with Colchicum autumnale. Crit Care 2004;8:R56-9, doi: 10.1186/cc2427.

14. Folpini A, Furfori P. Colchicine toxicity - clinical features and treatment. Massive overdose case report. 7 Clin Toxicol 1995;33:71-7, doi:10.3109/15563659509020219.

15. Putterman C, Ben-Chetrit E, Caraco Y, et al. Colchicine intoxication: clinical pharmacology, risk factors, features, and management. Semin Arthritis Rheum 1991;21:143-55, doi:10.1016/0049-0172(91)90003-I.

16. Murray SS, Kramlinger KG, McMichan JC, et al. Acute toxicity after excessive ingestion of colchicine. Mayo Clin Proc 1983;58:528-32.

17. Bismuth C, Fournier PE, Galliot M. Biological evaluation of hemoperfusion in acute poisoning. Clin Toxicol 1981;18: 1213-23, doi:10.3109/00099308109035060.

18. Harris R, Marx G, Gillett M, et al. Colchicine-induced bone marrow suppression: treatment with granulocyte colonystimulating factor. 7 Emerg Med 2000;18:435-40, doi: 10.1016/S0736-4679(00)00160-8.

19. Rae JM, Johnson MD, Lippman ME, et al. Rifampin is a selective, pleiotropic inducer of drug metabolism genes in human hepatocytes: studies with cDNA and oligonucleotide expression arrays. 7 Pharmacol Exp Ther 2001;299:849-57.

20. Westphal K, Weinbrenner A, Zschiesche M, et al. Induction of P-glycoprotein by rifampin increases intestinal excretion of talinolol in human beings: a new type of drug-drug interaction. Clin Pharmacol Ther 2000;68:345-55, doi:10.1067/ mcp.2000.109797.

21. Zhang L, Strong JM, Qiu W, et al. Scientific perspectives on drug transporters and their role in drug interactions. Mol Pharmacol 2006;3:62-9, doi:10.1021/mp050095h.

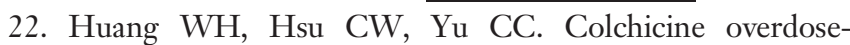
induced acute renal failure and electrolyte imbalance. Ren Fail 2007;29:367-70, doi:10.1080/08860220601166644.

23. Haylor J. Prostaglandin synthesis and renal function in man. 7 Physiol 1980;298:383-96.

24. Horackova M, Charvat J, Hasa J, et al. Life-threatening renal failure caused by vasomotor nephropathy associated with non-steroidal anti-inflammatory drugs. Int 7 Clin Pharmacol Res 2004;24:117-22.

25. Palmer BF, Henrich WL. Clinical acute renal failure with nonsteroidal anti-inflammatory drugs. Semin Nephrol 1995; 15:214-27.

26. Borras-Blasco J, Enriquez R, Sirvent AE, et al. Acute renal failure associated with an accidental overdose of colchicine. Int 7 Clin Pharmacol Ther 2005;43:480-4.

27. Venturini CM, Isakson P, Needleman P. Non-steroidal antiinflammatory drug-induced renal failure: a brief review of the role of cyclo-oxygenase isoforms. Curr Opin Nephrol Hypertens 1998;7:79-82, doi:10.1097/00041552-199801000-00013. 